\title{
INNOVATIVE SOLUTIONS IN THE PROCESS OF HEAT SUPPLY
}

doi: 10.2478/cqpi-2019-0021

Date of submission of the article to the Editor: 03/05/2019

Date of acceptance of the article by the Editor: 25/05/2019

\section{Aleksandra Wrzalik - orcid id: 0000-0002-3859-4954 \\ Czestochowa University of Technology - Poland}

\begin{abstract}
Heat supply is one of the most important sectors of the country's energy economy. Widely understood heating secures both: the living needs of society and industrial recipients. Modern heating systems should guarantee reliability of heat supply while limiting energy consumption and transmission losses. It results from the sustainable development strategy, implemented in the European Union, which is based on the development of renewable energy and improvement of energy efficiency. As a consequence of such an energy policy, investments and innovations are implemented in the two areas of the heating sector: technical infrastructure and management of the heat generation and transmission system. The article discusses legal as well as technical and economic conditions for the operation of heating companies, including aspects of energy security. The characteristics of the heat market in Poland and investment expenditures related to the modernisation of infrastructure and environmental protection has been presented in it. Selected innovations used in the process of heat production and supply have been described as well as modern technologies and IT tools that improve management of heating system. The possibilities and limitations of innovative heating development have also been indicted here.
\end{abstract}

Keywords: heat supply; district heating system, heating infrastructure; innovations

\section{INTRODUCTION}

Thermal power industry protects the living needs of society as well as industrial consumers, constituting an important element of the national economy. Heat in Poland is produced mainly in centralised sources (heat system). The process of supplying heat to customers takes place through a heating system that includes the following elements (Rak, 2017; Osiadacz et al., 2018):

- heat generating sources producing heat compliant with the right parameters, in the necessary quantity and at the right time,

- heating network supplying heating medium to recipients,

- heating nodes transforming heating medium with appropriate parameters,

- indoors installations which supply's individual receivers.

The current legal, technical and environmental conditions for the operation of heating companies, require expenditures, investment in the modernization of infrastructure 
and application of innovative solutions. These actions relate to the use of modern technologies of heat generation, economical methods of its transmission, as well as organizational changes. Technological innovations in district heating companies concern two areas: technical infrastructure and management of the heat generation and transmission system.

\section{DETERMINANTS OF THE HEATING PROCESS SUPPLY}

Heat supply is a complex process, which should take into account many problems in the areas of technology, ecology and economy, as well as the existence of a number of threats to security of heat supply (Rak, 2018). It is characteristic for the processes of heat production and use that the heat demand for space heating occurs only within a few months of the year (heating season). Furthermore, the amount of heat consumed by consumers during the heating season is depends directly on the weather conditions, especially the ambient temperature. Exploitation of heating systems should be performed in a flexible way, ensuring the reliability of heat supply with reduced power consumption, transmission losses and also taking into account the economic considerations and environmental impact. The energy security in district heating systems is mainly influenced by technical conditions, among other:

- balancing the demand side (current, regardless of weather conditions and prospective),

- technical condition of the heating infrastructure and its reliability,

- possibilities to manage efficiently the heating infrastructure.

The functioning of heat supply companies is subject to the interactions that result from the country's energy policy implemented in the regulation of the European Union's law. The main directions of the policy, defining the determinants for heating sector in Poland are:

- improving energy efficiency - increasing the efficiency of systems,

- development of innovative heating with the use of renewable energy sources (smart grids),

- energy security of heat supply,

- development of competitive fuel and energy markets,

- reduction of pollutant emissions and negative impact on the environment.

Improving energy efficiency is a priority associated with the implementation of the other above-mentioned objectives of the Polish energy policy. This is due to the implementation of the Directive of the European Parliament and of the Council 2012/27/EU on energy efficiency, which defined the notion as 'efficient district heating and cooling'. Meeting the efficiency conditions, specified in the Directive, requires the development of infrastructure of district heating systems, in the area of their adaptation to the use and development of high-efficiency cogeneration, including waste from heat and energy from renewable sources (Turski and Sekret, 2015, Osiadacz et al., 2016).

\section{CHARACTERISTICS OF THE HEATING SECTOR IN POLAND}

District heating systems in Poland cover an average of $65 \%$ of household heat demand. The source of heat is municipal heat and power plants, which provide usable hot water, as well as electricity generated in combination. The technical potential of the heating companies sector is determined by two basic values, i.e. installed 
thermal power and the length of heating networks. The basic values for system heating in Poland, according to the URE report (2018), have been presented in Table 1.

Table 1.

The potential of system heating in Poland in 2002, 2008 and 2017

\begin{tabular}{|c|c|c|c|c|}
\hline \multirow{2}{*}{ Specification } & \multirow{2}{*}{$\begin{array}{c}\text { Unit of } \\
\text { measure }\end{array}$} & \multicolumn{3}{|c|}{ Data in years } \\
\hline & & 2002 & 2008 & 2017 \\
\hline Number of licensed heating companies & - & 894 & 530 & 412 \\
\hline Thermal power installed & MW & 70952,8 & 61456,0 & 54911,8 \\
\hline Power ordered by recipients & MW & 38937,0 & 35461,1 & 33558,8 \\
\hline Length of heating networks & $\mathrm{km}$ & 17312,5 & 19104,1 & 21084,8 \\
\hline Annual heat production & TJ & 467527,8 & 396622,4 & 395596,9 \\
\hline Including cogeneration & TJ & no data & 250675,7 & 241614,8 \\
\hline Annual total heat sales & TJ & 469355,5 & 395861,4 & 379522,4 \\
\hline Heat delivered to the network & TJ & 336043,0 & 288061,0 & 276902,6 \\
\hline $\begin{array}{l}\text { Heat delivered to recipients connected to } \\
\text { the network }\end{array}$ & TJ & 298938,1 & 254156,1 & 242527,3 \\
\hline Average efficiency of heat transfer & $\%$ & 88,2 & 87,6 & 86,7 \\
\hline Decapitalisation ratio of fixed assets & $\%$ & 54,75 & 59,40 & 49,60 \\
\hline The average one-component price of heat & Zł/GJ & 28,37 & 32,61 & 48,33 \\
\hline
\end{tabular}

Source: own elaboration

In 2017 heating companies generated, along with heat recovered in technological processes, 395.6 thousand TJ of heat. Over $61 \%$ of heat was produced in sources, i.e. 241.6 thou. TJ was produced in cogeneration with the production of electricity. The total length of heating networks at the end of 2017 was over 21 thou. $\mathrm{km}$.

A positive phenomenon is a reduction of the decapitalisation ratio of fixed assets since 2008 , which decreased from $59.4 \%$ to $49.6 \%$ in 2017 . It's a result of making by the heating companies, investments in heat sources and transmission infrastructure, mainly from equity capital. The amount of expenditures according to the data of the URE Annual Report for 2008-2017 has been shown in Figure 1.

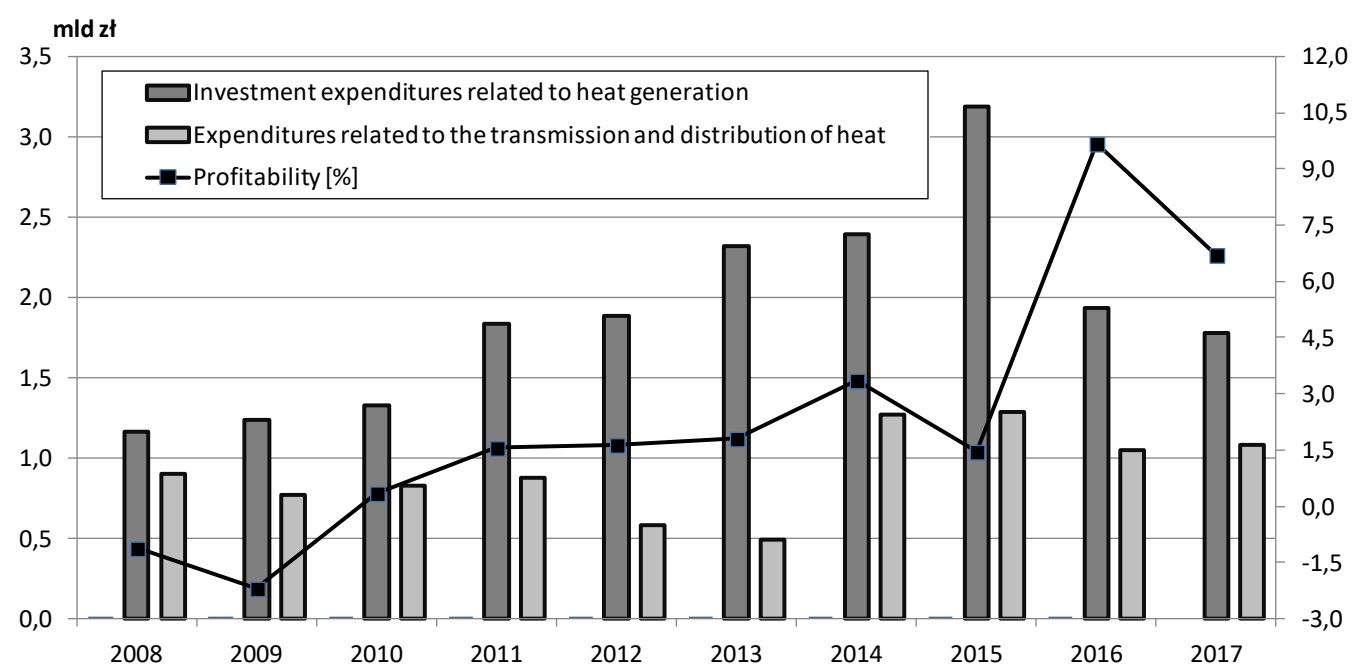

Fig. 1. Investments related to the modernisation of district heating systems in 2008-2017 
There is a noticeable increase in heat sources expenditures in 2011-2015 related to the improved profitability of the business and legal regulations for improving energy efficiency and reduction of emissions. After the investment period in heat generation systems, investment expenditure for the modernisation of the transmission network increased significantly from 2014.

\section{SELECTED INNOVATIONS IN HEATING SYSTEMS}

Improvement of technology and introduction of innovations in heating companies result from the conditions of the energy market (reduction of ordered power, reduction of heat costs for consumers, development of renewable energy and prosumer energy) and the need to ensure reliability of the heating system operation as well as the efficiency of the heat delivery process. Energy efficiency and reliability of the district heating network can be improved by (Turski and Sekret, 2015; Wojdyga and Chorzelski, 2017):

- reduction of heat transmission losses from heating pipelines,

- conducting hydraulic analyses for pipeline systems under various operating conditions (hydraulic adjustment),

- operation of a few heat sources for a joint network in the heating system,

- introducing IT tools of heat demand forecasting in the short (according to weather forecast) and long term,

- building systems of heat and power cogeneration (CHP) based on the demand for usable hot water,

- using heat reservoirs (especially in heat and power plants) to balance fluctuations in heat demand.

Innovations in district heating concern the two areas: technical infrastructure and management of the heat production and transmission system (Rak, 2018). Typical innovations implemented in heating companies have been presented in Table 2.

Table 2.

Typical innovations in heating companies

\begin{tabular}{|l|l|}
\hline \multicolumn{1}{|c|}{ Technical infrastructure } & \multicolumn{1}{c|}{$\begin{array}{c}\text { Management of heat generation and } \\
\text { transmission systems }\end{array}$} \\
\hline- use of heat accumulators, \\
- applying new technical solutions in the \\
form of pre-insulated pipes with an alarm \\
$\begin{array}{l}\text { system, } \\
\text { modification of the heat and electricity } \\
\text { production method (CHP units) and cold } \\
\text { production (CCHP systems), }\end{array}$ & $-\begin{array}{l}\text { automation of heat substations, } \\
\text { monitoring and controlling the operation } \\
\text { of the network, }\end{array}$ \\
$-\begin{array}{l}\text { implementation of fuels with a lower } \\
\text { environmental burden, }\end{array}$ & $\begin{array}{l}\text { asing IT tools to optimise and manage } \\
\text { account weather conditions, }\end{array}$ \\
$-\begin{array}{l}\text { cooperation network with the Renewable } \\
\text { Energy Sources }\end{array}$ & $-\begin{array}{l}\text { supporting business management, } \\
\text { market models for the regulation of heat } \\
\text { supply in heating systems. }\end{array}$ \\
\hline
\end{tabular}

Source: own elaboration

Innovative solutions in generation infrastructure relate to changes in the way of generating heat, electricity and cooling (CHP and CCHP systems), implementing fuels 
with lower environmental load (levels of dust, CO2, SO2 and NOx emissions) and using heat storage installations. The transmission infrastructure uses pre-insulated pipe systems with an alarm installation in the common isolation mantle.

In the area of management of heat generation and transmission systems, technological innovations rely on the use of IT tools and teletransmission systems (Rak, 2016). The use of distributed control systems and SCADA-type packages enables visualisation of the heating system's operation and remote control of the operation of individual devices. Visualisation systems facilitate ongoing exploitation and improve the economic efficiency of network management (Osiadacz et al., 2018). Implementation of software packages dedicated to the heating industry ensures ongoing control of the operation status of heating systems and provides an opportunity to analyse static and dynamic states occurring in real conditions (Olsthoorn et al., 2016). The structure of a modern IT system for monitoring and management of the heating system has been shown in Figure 2.

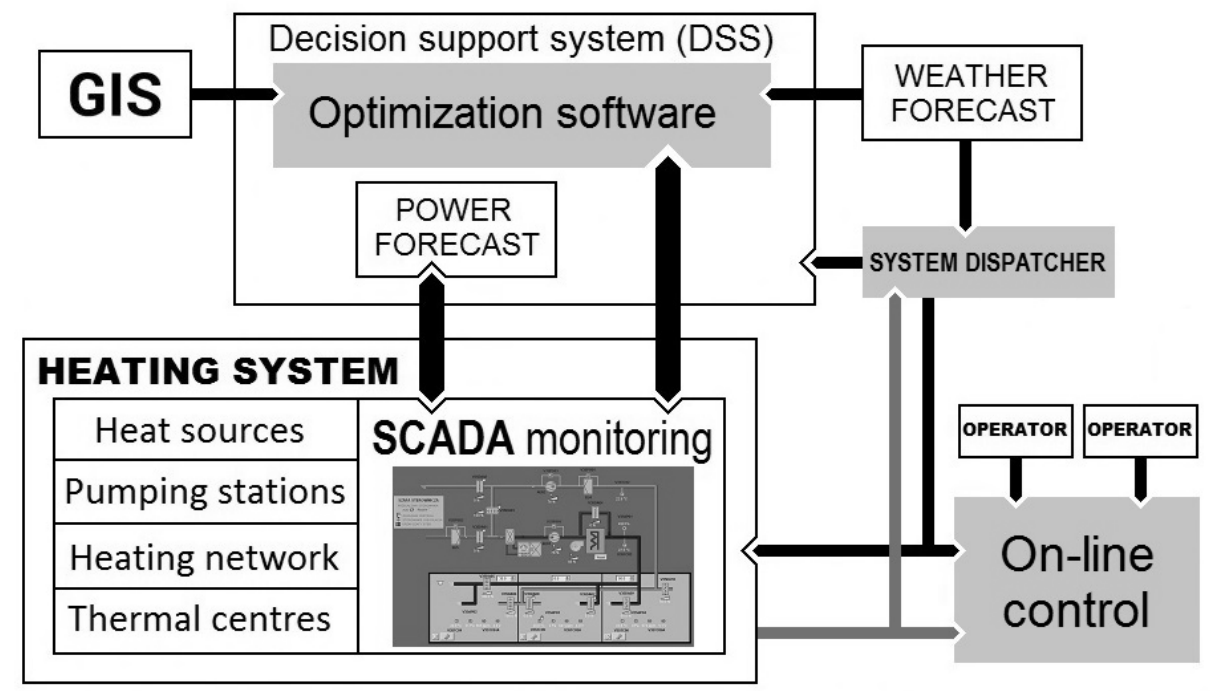

Fig. 2. A modern IT system for monitoring and management of the heating system

A comprehensive approach to the innovation management process in heating must include not only technological aspects but also organisational solutions and decisionmaking processes (Goffin and Mitchell, 2017; Tidd and Bessant, 2018).

\section{POSSIBILITIES AND LIMITATIONS OF THE DEVELOPMENT OF INNOVATIVE HEATING}

Heating systems must guarantee the continuity of heat supply to consumers despite the influence of external factors, usually independent of the producer and internal ones covering its management as well as the heat production and distribution processes. The basic factors affecting the directions and opportunities for the development of district heating systems have been included in Table 3 (Rak, 2018).

The future of heat supply systems is integrated heat networks within general sustainable energy systems using renewable energy sources - 4G-hybrid heating networks with reduced performance (Rezaie and Rosen, 2012). An important role in the generation of heat will be played by renewable energy sources, mainly dispersed, installed at end users and working in intelligent networks, e.g. in the configuration of building microgrids (BMGs). Each BMG has a local combined heat and power (CHP) 
unit, energy storage, renewables as well as electric and thermal loads (Bui et al., 2018). Significant reduction of losses in the heating network is possible as a result of lowering the network water temperature for CHP blocks. The advantages of low temperature district heating include: reduction of heat losses in the network, possibility of connecting many renewable heat sources (recipients), increased utilisation of thermal storage units and improving the power to heat ratio in the CHP system (Imran et al., 2017).

Table 3.

Factors influencing the directions and possibilities of development of heating systems

\begin{tabular}{|c|c|}
\hline Internal threats & External threats \\
\hline $\begin{array}{l}\text { - economic and financial situation of the } \\
\text { company, } \\
\text { - development strategy of the company } \\
\text { and implementation of technological } \\
\text { innovations, } \\
\text { - } \text { heat generation technology, } \\
\text { - the level of reserves in the heat source, } \\
\text { - technical condition of the infrastructure for } \\
\text { generating and transmitting heat, } \\
\text { - implementation of IT tools for monitoring } \\
\text { and management of the heating system, } \\
\text { - involvement of the management cadre, } \\
\text { - skills, experience and competences } \\
\text { of employees operating the heating } \\
\text { network. }\end{array}$ & $\begin{array}{l}\text { - } \text { macroeconomic conditions, } \\
\text { - technical and environmental } \\
\text { requirements, } \\
\text { - } \text { programs and funds promoting the } \\
\text { improvement of energy efficiency, } \\
\text { - } \text { financial support of the state for } \\
\text { innovative activity, } \\
\text { - } \text { development of energy-saving } \\
\text { construction technologies, } \\
\text { - } \text { development of prosumer energy and } \\
\text { micro-generation, } \\
\text { - climatic conditions, } \\
\text { - } \text { reliability of fuel supply and electricity, } \\
\text { - fuel price level (impact on costs and } \\
\text { profitability of operations). }\end{array}$ \\
\hline
\end{tabular}

Source: own elaboration

The use of an auxiliary heat storage pipe in a low-temperature district heating system enables heat exchange between the heat supplier and prosumers, who operate their own distributed energy generation unit. This allows to significantly mitigate the inefficiency arising from mismatching of heat demand and supply on the consumer's side (Im and Liu, 2018).

\section{CONCLUSION}

Changes in the national economy, requirements of the climate and energy policy, trends in heat demand while increasing energy security, pressure on heating companies to introduce innovative technologies. The correct assessment of the directions and range of changes in heat demand (development of microgeneration and prosumer energy) is an important determinant for the modernisation and development of smart grids heating systems. The necessary increase in the energy efficiency of the heating system in the first place requires improving the efficiency and reducing heat losses (4GDH systems). This applies to the modernisation of generating units and distribution networks, including realistic forecasts of heat demand, lowering the temperature of the heating medium, and also expanding the range of services (supply of hot water and cold - CHP and CCHP systems). A significant improvement of technical and economic indicators requires that modern intelligent network management technologies are used, which are related to the implementation of IT tools that support decision-making processes in the companies. 


\section{REFERENCES}

Annual Report: Thermal power industry in numbers - 2017, URE, Warszawa 2018.

Bui, V.H., Hussain, A., Kim, H.M., Im, Y.H., 2018. Optimal Energy Management of Building Microgrid Networks in Islanded Mode Considering Adjustable Power and Component Outages. Energies 2018, 11, 2351; doi:10.3390/en11092351

Directive 2012/27/EU of the European Parliament and of the Council of 25 October 2012 on energy efficiency, ... (OJ L 315 14.11.2012).

Goffin, K., Mitchell, R., 2017. Innovation Management: Effective Strategy and Implementation. Palgrave, London.

Im, Y.H., Liu, J., 2018. Feasibility study on the low temperature district heating and cooling system with bi-lateral heat trades model. Energy, 153, 988-999; DOI: 10.1016/j.energy.2018.04.094.

Imran, M., Usman, M., Im, Y.H., Park, B.S., 2017. The feasibility analysis for the concept of low temperature district heating network with cascade utilization of heat between networks. Energy Procedia, 116, 4-12.

DOI: 10.1016/j.egypro.2017.05.050.

Olsthoorn, D., Haghighat, F., Mirzaei, P.A., 2016. Integration of storage and renewable energy into district heating systems: $A$ review of modelling and optimization, Solar Energy, 136, 49-64. DOI: 10.1016/j.solener.2016.06.054.

Osiadacz, A.J., Blanco, D., Kajak, B., 2018. Nowoczesne zarządzanie siecią ciepłowniczą. Ciepłownictwo, Ogrzewnictwo, Wentylacja, 12/49, 479-485;

DOI: 10.15199/9.2018.12.1

Osiadacz A.J, Chaczykowski M., Kwestarz M., 2016. Systemy ciepłownicze w 2050 roku - perspektywy i wyzwania. Ciepłownictwo, Ogrzewnictwo, Wentylacja, 10/47, 391-399.

OECD/Eurostat (2018), Oslo Manual 2018: Guidelines for Collecting, Reporting and Using Data on Innovation, 4th Edition, The Measurement of Scientific, Technological and Innovation Activities, OECD Publishing, Paris/Eurostat, Luxembourg. https://doi.org/10.1787/9789264304604-en.

Rak, A., 2016. Narzędzia informatyczne do zarządzania i optymalizacji pracy systemu ciepłowniczego. Zeszyty Naukowe UE w Katowicach, 308, 115-127.

Rak, A., 2017. Selected aspects of hydraulic issues in heating systems. Production Engineering Archives, 14, 27-32.

Rak, A., 2018. Selected aspects of technological innovations management in district heating companies. MATEC Web of Conferences, 183.

DOI: $10.1051 /$ matecconf/201818304003.

Rezaie, B., Rosen, M.A., 2012. District heating and cooling: Review of technology and potential enhancements. Applied Energy, 93, 2-10.

DOI: 10.1016/j.apenergy.2011.04.020.

Tidd J., Bessant J.R, 2018. Managing Innovation: Integrating Technological, Market and Organizational Change. 6th Edition, John Wiley \& Sons Ltd, United Kingdom.

Turski, M., Sekret, R., 2015. Konieczność reorganizacji systemów ciepłowniczych $w$ świetle zmian zachodzących $w$ sektorze budowlano-instalacyjnym. Rynek Energii, 4, 27-34.

Wojdyga, K., Chorzelski, M., 2017. Chances for polish district heating systems. Energy Procedia, 116, 106-118, DOI: 10.1016/j.egypro.2017.05.059. 